\title{
PENGARUH PENERAPAN GOOD CORPORATE GOVERNANCE TERHADAP LEVERAGE DAN PROFITABILITAS PADA PERUSAHAAN PERBANKAN YANG TERDAFTAR DI BEI PERIODE 2009-2013
}

\author{
Riana Christel Tumewu \\ (email: n4n427itel_pooh@yahoo.co.id)
}

\begin{abstract}
Since the economic crisis of 1997, the implementation of good corporate governance, or better known as the Good Corporate Governance $(G C G)$ to issue raised in Indonesia. Due to poor corporate governance in Indonesia at that time, causing the economy to fall. So that everyone agrees to cover the difficulties Indonesia began with corporate governance. GCG or good corporate governance is a control mechanism to measure and manage the company, with the intention to improve corporate accountability. A good corporate governance (GCG) can be defined as a process and structure used by the organs of the company to enhance shareholder value.

The purpose of this study was to (1) Testing and proving the influence of good corporate governance to leverage, (2) To test and prove the effect of the application of good corporate governance on profitability, (3) To test and prove the effect of leverage on profitability. The object of this research is the banking companies listed on the Stock Exchange. The data used in this study is data banking companies listed on the Stock Exchange as many as 16 samples according to criteria of the study, with the vulnerable period of the data used is year 2009-2013.

The analytical method used is the analysis of the path. Results of data analysis using path analysis showed that the implementation of GCG Effect $(X)$ to leverage (Y1) for the ratio of DER (Y1-DER) and $D A R(Y 1-D A R)$ is not significant. Different results are obtained when the $G C G(X)$ showed a significant effect on profitability (Y2) for ROE (Y2-ROE) and NPM (NPM-Y2). As for the effect of leverage (Y1) to profitability (Y2) of the banking companies listed on the Stock Exchange tend to be varied. This means that the better the GCG implementation does not affect the banking company debt, but if the better implementation of GCG to profitability, it can enhance the company's ability to generate profits. Suggestions should the company become more motivated to implement GCG consistently in order to help improve the productivity and efficiency of a company that obviously affected the company's earnings that have an impact on investor confidence.
\end{abstract}

\section{Keywords : GCG, Profitability, and Leverage}

\section{PENDAHULUAN}

Sejak tahun 1997 terdapat salah satu faktor penyebab kritis yang melanda Asia termasuk Indonesia yang menyebabkan kebangkrutan perusahaan-perusahaan adalah lemahnya Tata Kelola Perusahaan (TKP). Lemahnya penerapan TKP antara lain adalah semakin terpisahnya antara hubungan para pemegang saham dengan manajemen, kurang transparan perusahaan mengenai kinerja keuangan, semakin tidak terkendalinya pengelolaan dan pengembalian keputusan perusahaan yang terkait dengan kelangsungan hidup perusahaan, dan tidak efektinya komite audit.

Krisis perbankan di Indonesia yang dimulai pada akhir tahun 1997 bukan semata-mata diakibatkan oleh krisis ekonomi, tetapi juga di akibatkan oleh belum di implementasikannya good corporate governance dan etika yang melandasinya. Banyak penyebab utama kegagalan bank yaitu salah satunya dengan adanya manajemen bank yang buruk, karena berani mengambil risiko, dan kurangnya pengawasan yang dilakukan terhadap tindak penipuan dan penggelapan dana. Oleh karena itu, usaha mengembalikan kepercayaan kepada dunia perbankan Indonesia melalui restrukturisasi dan rekapitalisasi, hanya dapat mempunyai dampak jangka panjang apabila disertai tiga tindakan penting, yakni: (1) Ketaatan terhadap prinsip kehati-hatian ; (2) Pelaksanaan Good Corporate Governance; (3) Pengawasan yang efektif dari otorisasi pengawasan bank.

Seiring dengan perkembangan pengelolaan perbankan yang ada, fungsi bank menjadi lebih luas,dan memiliki peran sentral dalam perkembangan ekonomi dan bisnis, kepercayaan menjadi faktor 
utama seseorang dalam mengalokasikan dana yang dimiliki ke dalam bank. Sementara itu masih terdapat bank yang menyalahgunakan kepercayaan tersebut sehingga merugikan pihak nasabah yang menyebabkan kepercayaan nasabah menurun.Salah satu penyebab penyalahgunaan kepercayaan itu terjadi karena kurangnya tata kelola yang baik dalam suatu perusahaan perbankan atau yang biasa kita kenal dengan Good Corporate Governance.Untuk itu Good Corporate Governance (GCG) sangat dibutuhkan dalam membangun kepercayaan masyarakat dan dunia internasional sebagai syarat mutlak bagi dunia perbankan untuk berkembang dengan baik dan sehat.

Menurut Marihot Nasution dan Doddy Setiawan (2007) menyebutkan bahwa Corporate Governance merupakan konsep yang diajukan demi peningkatan kinerja perusahaan melalui supervisi atau monitoring kinerja manajemen dan menjamin akuntabilitas manajemen terhadap stakeholder dengan mendasarkan kerangka peraturan.Adanya penerapan prinsip $G C G$ diharapkan dapat meningkatkan nilai perusahaan yang dicapai jika perusahaan mampu beroperasi dengan memenuhi laba yang ditargetkan.Adapun manfaat dari penerapan $G C G$ salah satunya yaitu meningkatkan produktifitas dan efisiensi perusahaan yang tentu saja berimbas besar terhadap laba perusahaan yang berdampak pada kepercayaan investor.

Secara teoritis perusahaan yang memiliki laba yang semakin besar akan lebih diminati oleh investor karena diharapkan dapat memberikan return yang lebih besar bagi investor apabila mereka melihat dan menganalisa laporan keuangan perusahaan terlebih dahulu. Sehingga sebelum mengambil keputusan untuk melakukan investasi, mereka menghindari segala sesuatu yang dapat menyebabkan kerugian dari investasi. Dengan adanya laba bersih yang baik maka akan berpengaruh pada kinerja perusahaan dilihat dari rasioleverage dan profitabilitasyang diukur denganDER, DAR,ROE, NPM.Penelitimerasa tertarik dengan latar belakang yang telah diuraikan sehingga melakukan penelitian dengan judul "Pengaruh penerapan Good Corporate Governance terhadap leverage dan profitabilitaspada perusahaan perbankan yang terdaftar di BEI 2009-2013". Berdasarkan uraian latar belakang masalah diatas, maka penelitian ini merumuskan masalah sebagai berikut.

1. Apakah penerapan goodcorporate governance (GCG) berpengaruh terhadap leverage?

2. Apakah penerapan good corporate governance $(\mathrm{GCG})$ berpengaruh terhadap profitabilitas?

3. Apakah leverageberpengaruh terhadap profitabilitas?

\section{TINJAUAN PUSTAKA, KERANGKA PEMIKIRAN, HIPOTESIS Teori Good Corporate Governance}

Dua teori utama yang terkait dengan corporate governance adalah stewardship theory dan agency theory.Stewardship theory dibangun di atas asumsi filosofis mengenai sifat manusia, yaitu bahwa manusia pada hakekatnya dapat dipercaya, mampu bertindak dengan penuh tanggungjawab, memiliki integritas dan kejujuran terhadap pihak lain. Dengan kata lain, stewardship theory memandang manajemen sebagai dapat dipercaya untuk bertindak dengan sebaik-baiknya bagi kepentingan publik maupun stakeholder.

Sementara itu, dalam teori keagenan (agency theory), hubungan agensi muncul ketika satu orang atau lebih (principal) memperkerjakan orang lain (agent) untuk memberikan suatu jasa dan kemudian mendelegasikan wewenang pengambilan keputusan kepada agent tersebut.

\section{Kerangka Pemikiran}

Berdasarkan latar belakang penelitian dan tinjauan pustaka, dapat diketahui bahwa $G C G$ merupakan suatu sistem yang mengatur bagaimana organisasi dioperasikan dan dijalankan dengan baik karena $G C G$ sebagai sarana interaksi yang mengatur antar struktur dan mekanisme yang menjamin adanya kontrol, namun tetap mendorong efisiensi dan kinerja perusahaan. Sebuah perusahaan akan mengalami peningkatan kinerja jika menerapkan $G C G$. Dalam penelitian ini peneliti tertarik untuk mengukur pengaruh $G C G$ terhadap leverage dan profitabilitas perusahaan dengan menggunakan rasio DER, DAR, ROE, NPMsehingga dirumuskan kerangka konseptual penelitian ini sebagai berikut : 


\section{Gambar 1}

Kerangka Pemikiran Teoritis

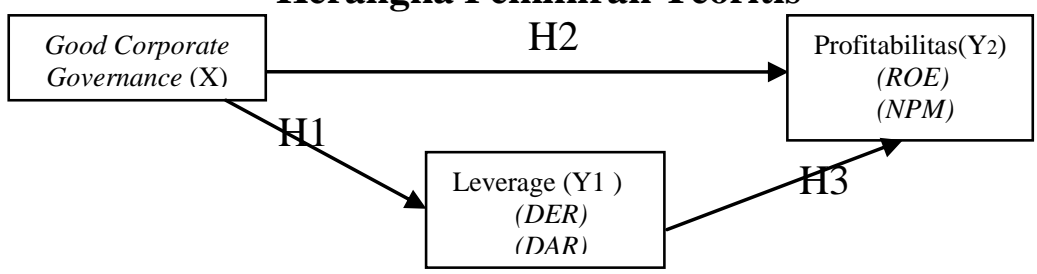

Sumber : Data Olahan (2014)

Penelitian ini menggunakan penerapan GCG sebagai variabel independen (variabel X) dan leverage sebagai variabel dependen (variabel Y1), profitabilitas sebagai variabel dependen (variabel Y2). Variabel $\mathrm{X}$ diukur dengan nilai komposit, untuk variabel Y1 yang diukur dengan menggunakan rasio debt to total assets ratio (DAR), debt to equity ratio (DER), dan untuk variabel Y2 diukur denganmenggunakanrasioreturn on equity (ROE), Net profit Margin (NPM).

\section{Hipotesis Penelitian \\ Pengaruh Penerapan GCG terhadap Leverage}

Leverage menunjukkan sejauh mana perusahaan dibiayai oleh hutang. Untuk leverage dapat dihitung dengan debt to total assets ratio (DAR) dan debt to equity ratio (DER). Syamsuddin (Dalam Purhadi, 2006:30) Rasio DAR ini digunakan untuk mengukur seberapa besar jumlah aktiva perusahaan dibiayai dengan total hutang. Semakin tinggi rasio ini berarti semakin besar jumlah modal pinjaman yang digunakan untuk investasi pada aktiva guna menghasilkan keuntungan bagi perusahaan.

DER merupakan perbandingan antara total utang yang dimiliki perusahaan terhadap total ekuitas. Analisis rasio ini dapat digunakan untuk menilai pendanaan yang dilakukan oleh perusahaan. Rasio utang terhadap ekuitas mengukur risiko struktur modal dalam hal hubungan antara dana yang dipasok oleh kreditor (utang) dan investor (ekuitas). Makin tinggi proporsi utang, maka makin besar tingkat risiko ekuitas karena kreditor harus dipenuhi sebelum pemilik dalam hal kebangkrutan. (Fraser dan Ormiston, 2008).

$\mathrm{H}_{1 \mathrm{a}}$ : $\mathrm{GCG}$ berpengaruh signifikan terhadap leverage

\section{Pengaruh Good Coorporate Governance Terhadap Profitabilitas}

Profitabilitas adalah kemampuan bank dalam menghasilkan keuntungan atau kemampuan bank dari berbagai sumber daya yang digunakan dalam kegiatan operasional.Sedangkan Rasio Profitabilitas menurut Mamduh M. Hanafi dan Abdul Halim (2005: 85) adalah rasio yang mengukur kemampuan perusahaan menghasilkan keuntungan (profitabilitas) pada tingkat penjualan, asset dan modal saham tertentu. Pada umumnya rasio profitabilitas bank dapat diukur dengan menggunakan beberapa rasio antara lainReturn on Asset, Return onEquity, dan Net profit margin.

Menurut Premuroso dan Bhattacharaya(2007) menunjukkan bahwa rasio-rasio yang mampu mewakili profitabilitas perusahaan seperti $R O E$ dan NPM memiliki hubungan positif signifikan dengan $G C G$. Sehingga makin baik pengelolaan perusahaan, maka perusahaan akan makin mampu menghasilkan tingkat imbal hasil yang lebih baik. Berdasarkan pada argumentasi diatas maka peneliti menetapkan hipotesis penelitian yaitu

$\mathrm{H}_{2 \mathrm{a}}$ : $\quad$ GCG berpengaruh signifikan terhadap profitabilitas

\section{Pengaruh Leverage Terhadap Profitabilitas}

Hutang dikatakan 'wajar' jika jumlahnya lebih kecil dari modal.Rasio hutang dapat berarti buruk pada situasi ekonomi sulit dan suku bunga tinggi, perusahaan yang memiliki debt ratio yang tinggi dapat mengalami masalah keuangan.Akan tetapi, selama kondisi ekonomi baik dan suku bunga rendah maka mereka dapat meningkatkan keuntungan.Keuntungan tersebut dapat dihitung atau diketahui melalui profitabilitas. 
Financial leverage adalah penggunaan sumber dana yang memiliki beban tetap dengan harapan bahwa akan memberikan tambahan keuntungan yang lebih besar daripada beban tetapnya sehingga akan meningkatkan keuntungan yang tersedia bagi pemegang saham (Sartono, 2010: 263).

$\mathrm{H}_{3 \mathrm{a}}$ : Leverage berpengaruh signifikan terhadap profitabilitas

\section{METODE PENELITIAN}

Populasi dan Sampel Penelitian

Populasi dalam penelitian ini adalah perusahaan yang terdaftar di BEI dari tahun 2009 - 2013.Dari populasi yang ada sebanyak 39 perusahaan perbankan akan diambil sejumlah 16 perusahaan perbankan sebagai sampel.

Metode pengambilan sampel yang akan digunakan dalam penelitian ini adalah metode purposive sampling. Adapun kriteria-kriteria yang digunakan dalam penelitian sampel adalah:

1. Terdaftar dalam Bursa Efek Indonesia dari tahun 2009 - 2013.

2. Merupakan perusahaan yang telah go public dari tahun 2009-2013.

3. Menerbitkan laporan keuangan lengkap dari tahun 2009 - 2013.

4. Laporan keuangan perusahaan disajikan dalam satuan Rupiah (Rp).

5. Penerapan GCG yang diukur dengan menggunakan nilai komposit.

\section{Klasifikasi Variabel dan Defenisi Operasional Variabel}

Variabel bebas (Independen Variabel) yang digunakan dalam penelitian ini adalah Penerapan GCG (X), Sementara variabel terikatnya (Dependen Variabel) adalah leverage ( $\left.\mathrm{Y}_{1}\right)$, profitabilitas $\left(\mathrm{Y}_{2}\right)$. Berikut ini akan dijelaskan operasionalisasi variabel-variabel yang dikaji dalam penelitian ini.

\section{Tabel 1}

\section{Operasional Variabel dan Pengukuran Variabel}

\begin{tabular}{|c|c|c|c|}
\hline Variabel & Indikator & Ukuran & Skala \\
\hline $\begin{array}{l}\text { Variabel } \\
\text { bebas: GCG }\end{array}$ & \begin{tabular}{lr}
\multicolumn{2}{l}{ Pengukuran penerapan good } \\
corporate & governance \\
dilakukan & dengan \\
menggunakan & nilai \\
yang dipublikasikan oleh BI.
\end{tabular} & $\begin{array}{l}\text { Nilai komposit dari perusahaan yang } \\
\text { diukur dan dikelompokkan dalam lima } \\
\text { tingkat, } \\
\text { yaitu: } \\
\text { a. Nilai komposit < 1,5 menunjukkan } \\
\text { kondisi sangat baik. } \\
\text { b. Nilai komposit 1,5-2,5 menunjukkan } \\
\text { kondisi baik. } \\
\text { c. Nilai komposit 2,3-3,5 menunjukkan } \\
\text { kondisi cukup baik. } \\
\text { d. Nilai komposit 3,5-4,5 menunjukkan } \\
\text { kondisi kurang baik. } \\
\text { e. Nilai komposit 4,5-5 menunjukkan } \\
\text { kondisi tidak baik. }\end{array}$ & NOMINAL \\
\hline $\begin{array}{l}\text { Variabel } \\
\text { terikat: } D A R\end{array}$ & $\begin{array}{l}\text { Debt to asset ratio }(D A R) \\
\text { Rasio ini digunakan untuk } \\
\text { mengukur seberapa besar } \\
\text { aktiva yang dibiayai dengan } \\
\text { hutang. }\end{array}$ & $D A R=$ Total Kewajiban / Total Aset & RASIO \\
\hline $\begin{array}{l}\text { Variabel } \\
\text { terikat: } D E R\end{array}$ & $\begin{array}{l}\text { Debt to Equity Ratio(DER) } \\
\text { merupakan rasio yang dapat } \\
\text { menunjukkan hubungan antara } \\
\text { jumlah pinjaman jangka } \\
\text { panjang yang diberikan oleh } \\
\text { kreditur dengan jumlah modal } \\
\text { sendiri yang diberikan oleh } \\
\text { pemilik perusahaan. }\end{array}$ & $\begin{array}{l}D E R=\text { Hutang Jangka Panjang/ Modal } \\
\text { Sendiri }\end{array}$ & RASIO \\
\hline
\end{tabular}




\begin{tabular}{|l|l|l|l|}
\hline Variabel & Indikator & Ukuran & Skala \\
\hline Variabel & $\begin{array}{l}\text { Return on Equity (ROE) } \\
\text { terikat: ROE } \\
\text { digunakan untuk mengukur } \\
\text { kemampuan bank dalam } \\
\text { memperoleh kaba Bersih / Modal Sendiri } \\
\text { bersih dikaitkan dengan } \\
\text { pembayaran dividen }\end{array}$ & RASIO \\
\hline $\begin{array}{l}\text { Variabel } \\
\text { terikat: }\end{array}$ & $\begin{array}{l}\text { Net Profit Margin (NPM) } \\
\text { adalah rasio yPM = Laba Bersih/Pendapatan } \\
\text { menggambarkan RASIO } \\
\text { keuntungan yang dingkat } \\
\text { bank dibandingkan dengan } \\
\text { pendapatan yang diterima dari } \\
\text { kegiatan operasionalnya. }\end{array}$ & & \\
& Operasional & \\
& & & \\
\end{tabular}

\section{HASIL PENELITIAN DAN PEMBAHASAN \\ Hasil Penelitian}

Dari hasil pengumpulan data sebanyak 39 perusahaan perbankan, diperoleh hasil bahwa hanya terdapat sebanyak 16 perusahaan perbankan sesuai kriteria penelitian yang terdaftar di Bursa Efek Indonesia. Data yang digunakan dalam penelitian ini adalah data sekunder yang berupa Leverage yang diukur dengan menggunakan rasio DER, DAR dan Profitabilitas yang diukur dengan menggunakan rasio $R O E$ dan $N P M$, dilihat dari laporan keuangan dan laporan tahunan yang melaporkan pelaksanaan $G C G$ di bank yang diteliti. Metode analisis yang digunakan dalam penelitian ini adalah dengan analisis jalur (path analysis).Sebelum melakukan analisis jalur, peneliti juga melakukan uji asumsi klasik yang memenuhiterdiri dari uji normalitas, uji autokorelasi dan uji heteroskedastisitas.

\section{Pembahasan}

Berdasarkan pada hasil penelitian atas besarnya koefisien jalur dari pengaruh GCG terhadap rasiorasio leverage (DER dan DAR) serta rasio-rasio profitabilitas (ROE dan NPM) di perusahaan perbankan yang terdaftar di BEI, dapat diketahui pula besarnya pengaruh langsung dari GCG dan Leverage terhadap Profitabilitas. Besarnya koefisien jalur yang menjelaskan pengaruh langsung dari GCG dan Leverage terhadap Profitabilitas perbankan yang terdaftar di BEI dapat dilihat pada Tabel 2 berikut.

Tabel 2

Koefisien Jalur Pengaruh LangsungGCG(X) terhadapLEVERAGE(Y1) dan Profitabilitas (Y2)

\begin{tabular}{|l|l|l|}
\hline \multicolumn{1}{|c|}{ Variabel } & Koefisien Jalur & $\begin{array}{l}\text { Pengaruh } \\
\text { Langsung }\end{array}$ \\
\hline GCG terhadap DER & -0.133 & -0.133 \\
\hline GCG terhadap DAR & -0.039 & -0.039 \\
\hline GCG terhadap ROE & 0.369 & 0.369 \\
\hline GCG terhadap NPM & 0.385 & 0.385 \\
\hline DER terhadap ROE & 0.150 & 0.150 \\
\hline DER terhadap NPM & -0.228 & -0.228 \\
\hline DAR terhadap ROE & 0.216 & 0.216 \\
\hline DAR terhadap NPM & -0.082 & -0.082 \\
\hline
\end{tabular}

Sumber : Hasil Olahan Data 2014

Hasil analisis data dengan menggunakan analisa jalur menunjukkan bahwa Pengaruh dari GCG $(\mathrm{X})$ terhadap leverage $\left(\mathrm{Y}_{1}\right)$ baik untuk rasio DER ( $\mathrm{Y}_{1-\mathrm{DER}}$ ) maupun DAR ( $\mathrm{Y}_{1-\mathrm{DAR}}$ ) adalah tidak signifikan. Hal ini berarti GCG memiliki pengaruh terhadap DER dan DAR perbankan yang terdaftar di BEI hanya saja pengaruh dari GCG tidaklah signifikan. 
Besarnya kontribusi pengaruh dari GCG terhadap $\mathrm{Y}_{1-\mathrm{DER}}$ adalah sebesar $\left(-0,133^{2}\right)$ atau berkontribusi negatif sebesar $1,77 \%$. Sisanya sebesar 98,23\% nilai DER perusahaan perbankan di BEI dijelaskan oleh variabel-variabel lain di luar penelitian dengan asumsi citeris paribus. Besarnya kontribusi pengaruh dari GCG terhadap $\mathrm{Y}_{1-\mathrm{DAR}}$ adalah sebesar $\left(-0,039^{2}\right)$ atau berkontribusi negatif sebesar 0,15\%. Sisanya sebesar 99,85\% nilai DAR perusahaan perbankan di BEI dijelaskan oleh variabel-variabel lain di luar penelitian dengan asumsi citeris paribus. Berdasarkan pada besarnya pengaruh dan pengujian statistika, maka dapatlah diketahui bahwa penerapan prinsip-prinsip GCG pada perbankan di BEI tidaklah memberikan pengaruh yang signifikan atas Leverage perusahaan perbankan di BEI.

Hasil yang berbeda diperoleh ketika GCG (X) diuji pengaruhnya terhadap profitabilitas $\left(\mathrm{Y}_{2}\right)$. Hasil pengujian menunjukkan pengaruh yang signifikan dari GCG terhadap profitabilitas $\left(\mathrm{Y}_{2}\right)$ baik untuk rasio ROE $\left(\mathrm{Y}_{2-\mathrm{ROE}}\right)$ maupun NPM $\left(\mathrm{Y}_{2-\mathrm{NPM}}\right)$. Dengan demikian, pelaksanaan prinsip-prinsip GCG perbankan yang terdaftar di BEI memberikan pengaruh yang signifikan terhadap profitabilitas yang dimiliki oleh perusahaan perbankan yang terdaftar di BEI.

Besarnya kontribusi pengaruh dari GCG terhadap $\mathrm{Y}_{2-\mathrm{ROE}}$ adalah sebesar $\left(0,369^{2}\right)$ atau berkontribusi positif sebesar $13,62 \%$. Sisanya sebesar $86,38 \%$ nilai ROE perusahaan perbankan di BEI dijelaskan oleh variabel-variabel lain di luar penelitian dengan asumsi citeris paribus. Besarnya kontribusi pengaruh dari GCG terhadap $\mathrm{Y}_{2-\mathrm{NPM}}$ adalah sebesar $\left(0,385^{2}\right)$ atau berkontribusi positif sebesar $14,82 \%$. Sisanya sebesar $85,18 \%$ nilai NPM perusahaan perbankan di BEI dijelaskan oleh variabelvariabel lain di luar penelitian dengan asumsi citeris paribus.

Pengaruh dari leverage $\left(\mathrm{Y}_{1}\right)$ terhadap profitabilitas $\left(\mathrm{Y}_{2}\right)$ dari perusahaan perbankan yang terdaftar di BEI cenderung bervariatif. Hasil penelitian menunjukkan bahwa leverage DAR ( $\mathrm{Y}_{1-\mathrm{DAR}}$ ) tidak berpengaruh signifikan terhadap rasio-rasio profitabilitas baik rasio ROE ( $\left.{ }_{2-\mathrm{ROE}}\right)$ maupun NPM ( $\left.\mathrm{Y}_{2-\mathrm{NPM}}\right)$.

Besarnya kontribusi pengaruh dari DAR terhadap $\mathrm{Y}_{2-\mathrm{ROE}}$ adalah sebesar $\left(0,216^{2}\right)$ atau berkontribusi positif sebesar 4,6\%. Sisanya sebesar 95,4\% nilai ROE perusahaan perbankan di BEI dijelaskan oleh variabel-variabel lain di luar penelitian dengan asumsi citeris paribus. Besarnya kontribusi pengaruh dari DAR terhadap $\mathrm{Y}_{2-\mathrm{NPM}}$ adalah sebesar $\left(-0,082^{2}\right)$ atau berkontribusi negatif sebesar $-0,7 \%$. Sisanya sebesar 99,3\% nilai NPM perusahaan perbankan di BEI dijelaskan oleh variabel-variabel lain di luar penelitian dengan asumsi citeris paribus.

Hal ini menunjukkan besarnya aset yang dibiayai oleh utang yang dimiliki oleh perusahaan perbankan di BEI tidak memberikan pengaruh yang signifikan terhadap kemampuan perusahaan perbankan dalam menciptakan pengembalian atas modal yang dimiliki (ROE), dan kemampuan perusahaan perbankan dalam menciptakan keuntungan jika dibandingkan dengan pendapatan yang diterima dari kegiatan operasionalnya (NPM).

Hasil penelitian yang menunjukkan adanya kontribusi negatif dari DAR terhadap NPM haruslah diwaspadai oleh perusahaan perbankan. Hal ini dikarenakan DAR memiliki potensi untuk mengurangi kemampuan perusahaan perbankan dalam menciptakan keuntungan jika dibandingkan dengan pendapatan yang diterima dari kegiatan operasionalnya (NPM).

Hasil yang berbeda ditunjukkan oleh hasil olahan data pengujian pengaruh dari leverage yaitu rasio DER ( $\left.\mathrm{Y}_{1-\mathrm{DER}}\right)$ terhadap ROE $\left(\mathrm{Y}_{2-\mathrm{ROE}}\right)$ dan NPM ( $\left.\mathrm{Y}_{2-\mathrm{NPM}}\right)$. Hasil penelitian menunjukkan bahwa DER tidak berpengaruh signifikan terhadap ROE, tetapi DER berpengaruh signifikan terhadap NPM.

Besarnya kontribusi pengaruh dari DER terhadap $\mathrm{Y}_{2-\mathrm{ROE}}$ adalah sebesar $\left(0,150^{2}\right)$ atau berkontribusi positif sebesar 2,2\%. Sisanya sebesar 97,8\% nilai ROE perusahaan perbankan di BEI dijelaskan oleh variabel-variabel lain di luar penelitian dengan asumsi citeris paribus. Besarnya kontribusi pengaruh dari DER terhadap $\mathrm{Y}_{2-\mathrm{NPM}}$ adalah sebesar $\left(-0,228^{2}\right)$ atau berkontribusi negatif sebesar $5,1 \%$. Sisanya sebesar 94,9\% nilai NPM perusahaan perbankan di BEI dijelaskan oleh variabel-variabel lain di luar penelitian dengan asumsi citeris paribus.

Hal ini berarti kemampuan perusahaan perbankan yang terdaftar di BEI dalam memenuhi kewajiban dengan ekuitas (DER) memiliki pengaruh yang mendorong kemampuan perusahaan dalam memberikan pengembalian atas ekuitas (ROE) hanya saja pengaruhnya tidak signifikan. Pengaruh yang signifikan dari DER terhadap NPM mengindikasikan kemampuan perusahaan perbankan yang terdaftar di BEI dalam memenuhi kewajiban dengan ekuitas (DER) memiliki pengaruh yang signifikan dan 
cenderung mengurangi kemampuan perusahaan perbankan dalam menciptakan keuntungan jika dibandingkan dengan pendapatan yang diterima dari kegiatan operasionalnya (NPM).

Kontribusi pengaruh yang bersifat negatif dan signifikan dari DER terhadap NPM menunjukkan akan adanya kecenderungan semakin tinggi rasio DER memberikan pengaruh yang bersifat mengurangi profitabilitas perusahaan. Rasio DER mengindikasikan besarnya modal yang dimiliki oleh perbankan yang diperoleh dari hutang, semakin tinggi DER akan memberikan dampak berkurangnya kemampuan menghasilkan pengembalian dari aktifitas operasional perbankan.Pengujian pada persamaan sub struktural 1-8, hanya persamaan sub struktural 3,4 dan 6 yang memberikan hasil signifikan. Hal ini berarti analisis jalur menunjukkan bahwa variabel GCG memiliki pengaruh yang signifikan terhadap profitabilitas baik rasio ROE maupun NPM.Leverage khususnya rasio DER memberikan pengaruh yang signifikan terhadap NPM. Secara grafik, hasil analisis jalur dapat digambarkan sebagai berikut.

Gambar 2. Pengaruh GCG terhadap Leverage dan Profitabilitas

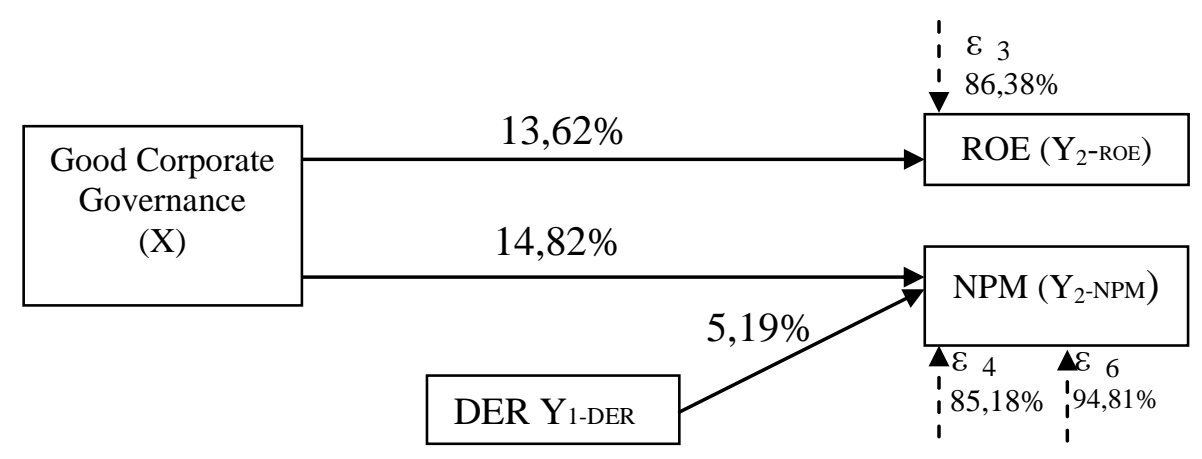

Gambar 2 menunjukkan bahwa penerapan GCG tidak pengaruh signifikan terhadap leverage, oleh karena itu $\mathrm{H}_{1 \mathrm{a}}$ dalam penelitian ini tidak diterima. Penerapan GCG pada perusahaan perbankan yang terdaftar di BEI memberikan pengaruh yang signifikan terhadap profitabilitas bank tersebut, seperti menurutPremuroso dan Bhattacharaya (2007) yang menunjukkan bahwa rasio-rasio yang mampu mewakili profitabilitas perusahaan seperti ROE dan NPM memiliki hubungan positif signifikan dengan GCG, oleh karena itu $\mathrm{H}_{2}$ a dalam penelitian ini diterima. Dari kedua rasio DAR, DER yang digunakan dalam penelitian ini hanya rasio DER yang memberikan pengaruh yang signifikan terhadap NPM, oleh karena itu $\mathrm{H}_{3}$ a dalam penelitian ini masih belum bisa diterima.

Perusahaan yang besar lebih diperhatikan oleh masyarakat sehingga akan lebih berhati-hati dalam melakukan pelaporan keuangan sehingga berdampak perusahaan tersebut melaporkan kondisinya lebih akurat (Nasution dan Setiawan, 2007). Penerapan GCG yang telah diwajibkan oleh Bank Indonesia mengharuskan perbankan di Indonesia mengelola bisnis mereka secara baik. Semakin baik penerapan GCG maka akan makin meningkat kemampuan perusahaan dalam menghasilkan laba. Hal ini mendukung penelitian Tjondro dan Wilopo (2011) yang menyatakan bahwa dengan penerapan GCG akan meningkatkan kinerja perusahaan secara positif karena proses pengambilan keputusan akan berlangsung secara lebih baik sehingga akan menghasilkan keputusan yang optimal, dapat meningkatkan efisiensi serta terciptanya budaya kerja yang lebih sehat.

\section{PENUTUP}

\section{Kesimpulan}

Berdasarkan dari hasil penelitian dan pembahasan pengaruh penerapan GCGterhadap DER, DAR dan ROE, NPM maka dapat disimpulkan beberapa kesimpulan sebagai berikut:

1. GCG berpengaruh tidak signifikan terhadap Leverage perusahaan perbankan yang terdaftar di Bursa Efek Indonesia. Hal ini berarti, semakin baik penerapan $G C G$ maka tidak berpengaruh terhadap hutang perusahaan perbankan yang ada. Semakin tinggi rasio hutang ini maka semakin besar resiko yang dihadapi perusahaan dan tidak akan berpengaruh terhadap GCG. Leverage dalam hal ini diukur dengan menggunakan rasio $D A R$ dan $D E R$. 
2. GCG berpengaruh signifikan terhadap profitabilitas perusahaan perbankan yang terdaftar di Bursa Efek Indonesia. Hal ini berarti pengaruh dari GCG terhadap profitabilitas ini akan meningkatkan kinerja perusahaan secara positif karena dapat menghasilkan keputusan yang optimal, dapat meningkatkan efisiensi serta terciptanya budaya lingkungan kerja yang baik dan lebih sehat. Semakin baik penerapan GCG maka akan makin meningkat kemampuan perusahaan dalam menghasilkan laba yang berdampak pada kepercayaan investor sebelum mengambil keputusan untuk melakukan investasi dan menghindari segala sesuatu yang dapat menyebabkan kerugian dari investasi, dalam hal ini diukur dengan menggunakan rasio ROE dan NPM.

3. DER memberikan pengaruh yang signifikan terhadap NPM pada perusahaan perbankan yang terdaftar di BEI. Hal ini berartimengindikasikan kemampuan perusahaan perbankan yang terdaftar di BEI dalam memenuhi kewajiban dengan ekuitas (DER) memiliki pengaruh yang signifikan dan cenderung mengurangi kemampuan perusahaan perbankan dalam menciptakan keuntungan jika dibandingkan dengan pendapatan yang diterima dari kegiatan operasionalnya (NPM).

\section{Saran}

Berdasarkan hasil penelitian yang telah dilakukan ini, peneliti dapat memberikan saran sebagai acuan bagi pihak yang berkepentingan:

1. Bagi Investor

Bagi para investor yang akan melakukan investasi pada perusahaan, lebih baik memilih perusahaan yang memiliki predikat komposit GCG yang sangat baik, karena penerapan GCGpada perusahaan dapat meningkatkan produktifitas dan efisiensi perusahaan yang tentu saja berpengaruh terhadap laba perusahaan dan kinerja keuangan suatu perusahaan. Dengan adanya penerapan GCG, maka tentunya laporan keuangan yang dihasilkan dapat diungkapkan secara transparan dan akurat, sehingga dapat menghindari kerugian terhadap para investor. Hal ini telah terbukti dalam penelitian ini semakin baik rasio perusahaan maka semakin tinggi pula penerapan GCG perusahaan tersebut.

2. Bagi Manajemen Perusahaan

Sesuai dengan keputusan Bank Indonesia, setiap perusahaan perbankan yang go public ditetapkan untuk menerapkan GCG yang tentu saja berdampak baik bagi perusahaan perbankan. Untuk itu dari hasil penelitian ini, sebaiknya manajemen perusahaan menjadi lebih termotivasi untuk menerapkan $G C G$ secara konsisten agar tentunya dapat membantu meningkatkan kinerja keuangan perusahaan.

\section{DAFTAR PUSTAKA}

Bank Indonesia. 2006. Peraturan Bank Indonesia Nomor 8/4/PBI/2006 Tentang Pelaksanaan Good Corporate Governance Bagi Bank Umum. (online), (www.bi.go.id, diakses pada 16 April 2014).

Bank Indonesia. 2006. Peraturan Bank Indonesia Nomor 8/14/PBI/2006 Perubahan Peraturan Bank Indonesia Nomor 8/4/PBI/2006 Tentang Pelaksanaan Good Corporate Governance Bagi Bank Umum. (online), (www.bi.go.id, diakses pada 16 April 2014).

Bank Indonesia. 2013. Peraturan Bank Indonesia Nomor 15/15/DPNP/2013 Tentang Pelaksanaan Good Corporate Governance Bagi Bank Umum. (online), (www.bi.go.id, diakses pada 16 April 2014).

Chinn, Richard, Corporate Governance Handbook, Gee Publishing Ltd. London, 2000.

Daniri, Mas. 2005. Good Corporate Governance Konsep dan Penerapannya Dalam Konsep Indonesia. Ray Indonesia, Jakarta.

Dani Riandi dan Hasan Sakti Siregar.2011. Pengaruh Penerapan Good corporate Governance terhadap ROA, NPM dan EPS pada Perusahaan yang Terdaftar di CGPI.Jurnal Ekonomi Volume 14 Nomor 3.

David Tjondro dan Wilopo, R. 2011.Pengaruh Good Corporate Governance (GCG) Terhadap Profitabilitas dan Kinerja Saham Perusahaan Perbankan yang Tercatat di Bursa Efek Indonesia.Journal of business \& banking.

Emirzon,Joni.2007. Prinsip-Prinsip Good Corporate Governance : Paradigma Baru Dalam Praktik Bisnis Indonesia. Yogyakarta: Genta Press. 
Ferry Andriawan Pramono. 2011. “Analisis Pengaruh Karakteristik Perusahaan Terhadap Kualitas Pengungkapan Corporate Governance Pada Laporan Tahunan (Studi Empiris Pada Perusahaan Yang Terdaftar Dalam LQ45)". Skripsi. Universitas Diponegoro.

FCGI, 2001. Corporate Governance: Tata Kelola Perusahaan. Edisi Ketiga, Jakarta.

Ghozali, Imam, 2006. Aplikasi Analisis Multivariat dengan Program SPSS. Cetakan Ke IV, Badan Penerbit Universitas Diponegoro, Semarang.

Hanafi, Mamdah M dan Abdul Halim, Analisa Laporan Keuangan, Edisi Pertama, UPP AMP YKPN, 2005.

Http://www.bpkp.go.id. ditelusuri pada tanggal 10 Mei 2014.

IDX. Laporan Tahunan Publikasi. www.idx.co.id diakses 10 Mei 2014. Manado.

Indah Sulistiyowati, Ratna Anggraini, dan Tri Hastuti Utaminingtyas. 2010. "Pengaruh Profitabilitas, Leverage, dan Growth terhadap Kebijakan Deviden dengan Good Corporate Governance sebagai Variabel Intervening”. Simposium Nasional Akuntansi XIII AKMEN-35.

Johan Wahyudi. 2010. "Pengaruh Pengungkapa Good Corporate Governance,Ukuran Dewan Komisaris Dan Tingkat Cross-Directorship Dewan Terhadap Nilai Perusahaan". Skripsi. Universitas Diponegoro.

Komite Nasional Kebijakan Governance.2006. Pedoman Umum Good Corporate Governance. Jakarta. KNKG

Lukman Dendawijaya. 2009. Manajemen Perbankan. Jakarta. Ghalia Indonesia

Nasution, Marihot dan Doddy Setiawan. 2007. Pengaruh Corporate Governance terhadap Manajemen Laba di Industri Perbankan Indonesia. Simposium Nasional Akuntansi X. Makassar 26-28 Juli 2007.

Nurly Arninda. 2011. "Pengaruh Penerapan Good Corporate Governance Terhadap Nilai Pasar Perusahaan Periode 2003-2009 Yang Terdaftar Di Bursa Efek Indonesia”. Skripsi.Universitas Negeri Yogyakarta.

Purwantini, V.T. 2011.Pengaruh Mekanisme Good Corporate Governance Terhadap Nilai Perusahaan dan Kinerja Keuangan Perusahaan yang Terdaftar di Bursa Efek Indonesia.Jurnal Ekonomi Bisnis dan Perbankan, 19(19), STIE AUB, Surakarta.

Premuroso, Ronald F. dan Somnath Bhattacharya. 2007. ’Is There a Relationship between Firm Performance, Corporate Governance, And a Firms Decision to Form a Technology Committee?”. Journal Compilation.Vol. 15.No. 6. p. 1260 - 1276.

Sarjono Haryadi, dan Julianita Winda. 2011. "SPSS vs LISREL”. Penerbit Salemba Empat: Jakarta.

Shaw, John. C, Corporate Governance and Risk: A System Approach, John Wiley \& Sons, Inc, New Jersey, 2003.

Retno, R.D., Printinah, D. 2012. Pengaruh Good Corporate Governance dan Pengungkapan Corporate Social Responsibility terhadap Nilai Perusahaan yang Terdaftar Di Bursa Efek Indonesia Periode 2007-2010. Jurnal Nominal, 1(1).

Suad Husnan \& Pudjiastuti, Enny. 2007. Dasar-dasar Manajemen Keuangan. Yogyakarta : UPP AMP YKPM.

Zarkasyi, Moh. Wahyudi. 2008. Good Corporate Governance. Alfabeta. Bandung. 